\title{
Perilaku Konsumen Memilih Produk Perbankan Syariah Pekanbaru
}

\author{
IDEL WALDELMI \\ Dosen Tetap Universitas Lancang Kuning \\ Jln. Yos Sudarso Km 08 Rumbai Pekanbaru Telp. (0761) 52581 \\ E-mail : idelwaldelmi@unilak.ac.id
}

\begin{abstract}
Consumer behavior on Sharia Banking Product becomes a phenomenon raised in this research. This is because most of the Islamic banking products have no demand. Through the type of survey research and data collected by using questionnaires obtained research results that of four variables can be seen the value of the first regression coefficient of service quality of 0.426 then the system for the results of 0.550 and culture of 0.144 serrta bank characteristics of 0.993 then it shows that of the four variables namely the quality of service, profit sharing system, culture, and bank characteristics proved variable characteristics of the bank gives a significant influence in comparison with other variables, followed by profit sharing system, service quality and the last culture
\end{abstract}

Keywords: service quality, profit sharing system, culture, bank characteristics, consumer behavior, syariah bank

Perkembangan Ekonomi Islam di Pekanbaru ditandai dengan beroperasinya Bank Muammalat Indonesia pada tahun 1999, dengan dikeluarkannya UU No.7 tahun 1992 tentang perbankan syariah. Perkembangan perbankan syariah di Pekanbaru tidak terlepas dari sistem perbankan di Indonesia secara umum. Sistem perbankan syariah sebagaimana diatur dalam Undang - undang No. 10 tahun 1998, disebutkan bahwa bank umum adalah bank yang melaksanakan kegiatan usaha secara konvensional atau berdasarkan prinsip syariah yang kegiatannya memberikan jasa dalam lalu lintas pembayaran. Dukungan terhadap pengembangan perbankan syariah juga diperlihatkan dengan adanya "dual banking system”, dimana bank konvensional diperkenankan untuk membuka unit usaha syariah.

Peran bank syariah dalam memacu pertumbuhan perekonomian daerah semakin strategis walaupun disadari bahwa pemahaman dan sosialisasi terhadap masyarakat tentang produk dan sistem perbankan syariah di Indonesia masih sangat terbatas.
Pertumbuhan penduduk Riau diatas standar Nasional $(1,3 \%)$ dan Riau (4.46\%). Jumlah penduduk di Provinsi Riau mengalami peningkatan yang cukup signifikan. Untuk 2010, angka pertumbuhan penduduk di Riau mencapai angka 4,46 persen dengan 5.543.031 jiwa. Pertumbuhan penduduk ini tergolong tinggi dan di atas standar nasional diangka 1,3 persen. Hanya saja, tingginya pertumbuhan penduduk di Provinsi Riau disebabkan faktor lain selain angka kelahiran dan kematian, yakni angka migrasi dan perpindahan penduduk.

Asisten II Setdaprov Riau Emrizal Pakis kepada Riau Pos, Rabu (1/6). "Tingginya angka pertumbuhan penduduk di Riau dari migrasi, menunjukkan Riau memiliki potensi yang besar dari berbagai sektor. Baik untuk investasi, pengembangan usaha, perdagangan dan sektor ekonomi lainnya. Ini hendaknya menjadi suatu nilai tambah dalam mengembangan potensi ekonomi daerah," ungkapnya. Dia menambahkan tingginya angka pertumbuhan penduduk tersebut dapat dilihat dari salah satu indikator perkembangan bisnis developer yang semakin menjamur. Hal ini melihat 
bahwa tingginya angka permintaan akan keperluan akan sarana tempat tinggal. Dari hasil sensus Badan Pusat Statistik juga diketahui jumlah penduduk Provinsi Riau 5.543031 jiwa.

Distribusi penduduk menurut kabupaten/kota menunjukkan bahwa penduduk Riau terkonsentrasi di Kota Pekanbaru sebagi ibu kota provinsi dengan jumlah penduduk 903.902 jiwa atau sekitar 16,31 persen dari seluruh penduduk Riau. Sektor perbankan yang memiliki posisi strategis sebagai lembaga keuangan semakin menyatu dengan ekonomi regional, nasional dan ekonomi internasional yang perkembagannya bergerak cepat dengan tantangan yang semakin kompleks. Perbankan dalam melaksanakan tiga fungsi utama yaitu menghimpun dana dari masyarakat sebagai pemilik dana, menyalurkan dana kepada masyarakat sebagai pengguna dana dan memberikan jasa.

Pembiayaan Mudharabah, Musyarakah dan Murabahah sera Ijarah dan lainnya merupakan pembiayaan yang banyak diminati di bank syariah. Terbukti dari data tahunan perbankan syariah 2012 yang dipublikasikan oleh Bank Indonesia tercatat piutang Murabahah paling mendominasi sebesar Rp 52,06 triliun diikuti oleh pembiayaan Musyarakah sebesar Rp 17,73 triliun. Dalam mengoptimalkan pencapaiannya, perbankan syariah berkomitmen untuk menggerakkan sektor riil secara terus menerus. Di mana dalam menggerakkan sektor riil ini, pembiayaan sebagai upaya finansial dari perbankan syariah telah mendapat perhatian yang tinggi sebesar $78,72 \%$. Dari uraian di atas dapat di simpulkan bahwa perkembangan perbankan syariah yang semakin meningkat tiap tahunnya. Perkembangan tersebut membawa angin segar bagi para pengusaha muslim atau pun non muslim dalam menggunakan jasa pembiayaan di bank syariah. Sebagaimana diketahui bahwa bank syariah merupakan bank yang dalam operasinya tidak mengandalkan bunga sebagai dasar dalam pengambilan keuntungan. Maka hal ini menjadi daya tarik tersendiri bagi para calon nasabah dalam perencanaan pengambilan pembiayaan di bank syariah (Qodriasari, 2014).

The American Marketing
Association dalam Setiadi (2003) menyatakan bahwa perilaku konsumen merupakan interaksi dinamis antara afeksi \&kognisi, perilaku, dan lingkungannya dimana manusia melakukan kegiatan pertukaran dalam hidup mereka. Kotler (2000) menyebutkan dalam Wahyuni (2008), bahwa faktor-faktor yang mempengaruhi perilaku konsumen antara lain : faktor kebudayaan, faktor sosial, faktor personal dan faktor psikologis. (Wiwiek Rabiatul Adawiyah, 2010) Pengetahuan konsumen terhadap bank syariah masih terbatas, sebagian besar responden hanya mengetahui tentang riba dan sya- riah. Sedangkan istilah-istilah dalam perbankan syariah seperti Ijarah, Mudharabah, Musyarakah, Murabahah dan lainnya masih belum diketahui dan dimengerti oleh konsumen. Alasan utama konsumen menabung di bank syariah adalah karena kombinasi dari alasan agama dan alasan keuntungan.

Melihat dari produk yang dimiliki oleh bank syariah yang ada kota pekanbaru baik itu Bank Muamalat, BRI Syariah, Bank Riau Syariah, BTN Syariah, BNI Syariah dan Bank Syariah Mandiri serta bank syariah lainnya. Pertumbuhan bank Syariah di kota pekanbaru sangat cepat dan pesat. Sudah sepantasnya masyarakat kota pekanbaru dengan sebutan Bumi Melayu Lancang Kuning mengkomsumsi produk ini dengan konsep Islam dan Melayu identik dengan Islam.

Dalam ushul figh, ada kaidah yang menyatakan bahwa " maa laa yatimm al wajib illa bihi fa huwa wajib”, yakni sesuatu yang harus ada untuk menyempurnakan yang wajib, maka ia wajib diadakan. Mencari nafkah ( yakni melakukan kegiatan ekonomi) adalah wajib. Dan karena pada zaman modern ini

$$
\text { p.ISSN: 2407-800X e.ISSN: 2541-4356 }
$$


kegiatan perekonomian tidak akan sempurna tanpa adanya lembaga keuangan perbankan, lembaga keuangan ini pun wajib diadakan. Dengan demikian, maka kaitan antara islam dengan perbankan menjadi jelas.

Di samping itu, seperti yang sudah disinggung diatas, kita mengetahui bahwa kerena masalah ekonomi/ perbankan ini termasuk kedalam bab muamalah, maka nabi Muhammad Saw. tentunya tidak memberikan aturan - aturan rinci mengenai masalah ini. Bukankah nabi sendiri , bahwa " antum a'laamu bi umuri al- dunyakum"? (kalian lebih mengetahui urusan dunia kalian).

Pembiayaan Mudharabah, Musyarakah, Murabahah, Salam, Istisna dan lainnya

\section{Mudharabah}

Mudharabah berasal dari kata dharb, berarti memukul atau berjalan. Pengertian memukul atau berjalan ini lebih tepatnya adalah proses seseorang memukulkan kakinya dalam menjalankan usahanya. Secara teknis, mudharabah adalalah akad kerja sama atau usaha antara dua pihak di mana pihak pertama sebagai pemilik dana (shohibul mal) menyediakan seluruh (100\%) modal, sedangkan pihak lainnya menjadi pengelola (mudharib). Keuntungan usaha jenis pembiayaan mudharabah dibagi menurut kesepakatan yang dituangkan dalam kontrak, sedangkan apabila rugi ditanggung oleh pemilik modal selama kerugian itu bukan akibat kelalaian si pengelola Seandainya kerugian itu diakibatkan karena kecurangan atau kelalaian si pengelola, si pengelola harus bertanggung jawab atas kerugian tersebut.

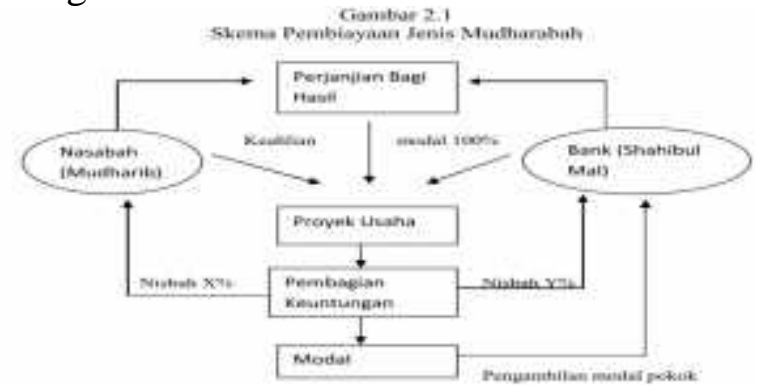

Sumber : Bank Syariah, dari Teori ke Praktik, Antonio, (2001)
Musyarakah (Partnership, Project Financing Participation)

Musyarakah adalah akad kerja sama antara dua pihak atau lebih untuk suatu usaha tertentu dimana masing-masing pihak memberikan kontribusi modal (atau amal/ expertise) dengan kesepakatan bahwa keuntungan dan risiko akan ditanggung bersama sesuai dengan kesepakatan. Berbeda dengan mudharabah, dalam pembiayaan jenis musyarakah pihak pengusaha/ nasabah (mudhorib) menambahkan sebagaian modalnya sendiri pada modal yang disediakan oleh shahibul mal, maka mudhorib/ nasabah tersebut membuka diri terhadap risiko kehilangan modal. Adanya tambahan modal dari nasabah (mudharib) maka ia dapat mengklaim suatu persentase bagi hasil yang lebih besar.

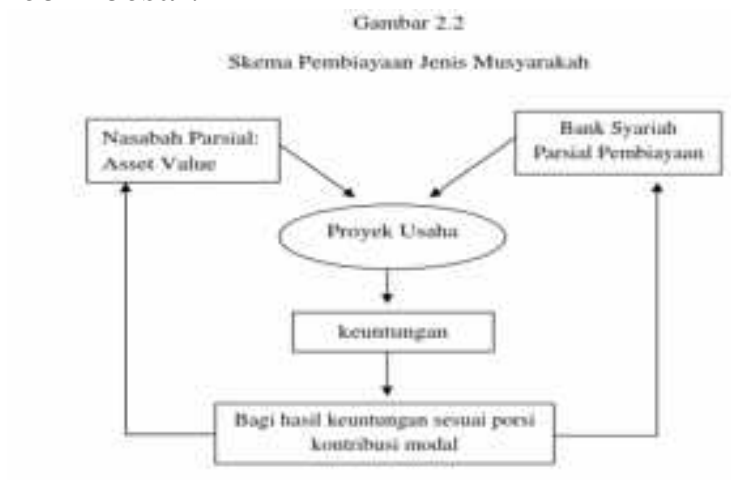

Sumber, Dumk Syariah, daut Teas ke Praktiz, Antranie [200!)

Murabahah

Murabahah dalam istilah fiqh ialah akad jual beli atas barang tertentu. Antonio (2001) menyebutkan murabahah adalah jual beli barang pada harga asal dengan tambahan keuntungan yang disepakati. Murabahah dalam teknis perbankan adalah akad jual beli antara bank selaku penyedia barang dengan nasabah yang memesan untuk membeli barang. Bank memperoleh keuntungan jual beli yang disepakati bersama. Harga jual bank adalah harga beli dari supplier ditambah keuntungan (mark up/margin) yang disepakati bersama. Jadi, nasabah mengetahui keuntungan yang diambil oleh bank. Selama akad belum berakhir, maka harga jual beli tidak boleh 
berubah, apabila terjadi perubahan, akad tersebut menjadi batal, cara pembayaran dan jangka waktu yang disepakati bersama, dapat langsung atau secara angsuran.

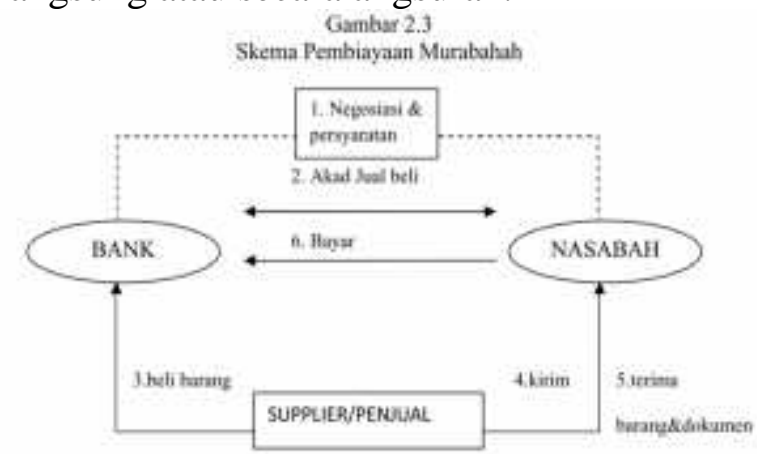

Sumber: Bank Syariah, dari Teori ke Praktik, Antwooo (200)

Pembiayaan Salam

Salam merupakan pembelian suatu barang yang penyerahannya dilakukan kemudian hari sedangkan pembayarannya dilaksanakan di muka secara tunai. Pembiayaan ini biasanya diaplikasikan pada pembiayaan berjangka pendek untuk produksi agribisnis atau hasil pertanian atau industri lainnya. Transakasi salam ini menyerupai praktik ijon yang masih ditemukan di desa-desa. Dalam praktek ijon, barang yang dibeli tidak dihitung atau diukur secara spesifik. Penentuan harga tidak transparan, cenderung sepihak, dan sangat memberatkan pihak penjual. Dalam salam kesepakatan antara pembeli dan penjual meliputi harga, ukuran kuantitas, kualitas, dan yang paling penting adalah harga barang dibayar di muka secara tunai

Gambar 2.4

Skema Permbiayaan Salam

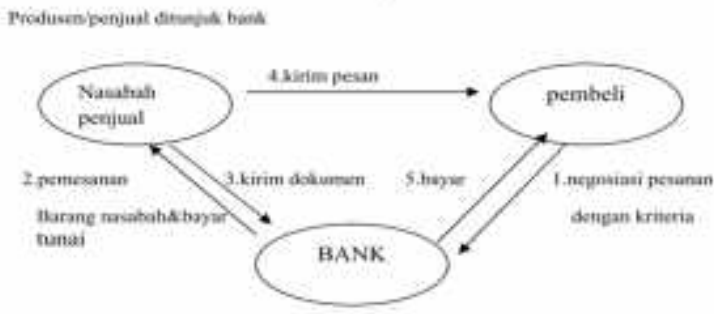

Sumber: Bank Syariah, dari Teari ke Praktik, Amonia (2001)

Istisna

Istishna merupakan kontrak penjualan antara pembeli dan pembuat barang dengan pembayaran di muka, bak dilakukan dengan cara tunai, cicil, atau ditangguhkan. Kontrak dibuat di tempat pembuat barang. Prinsip istishna menyerupai salam, namun dalam istishna pembayaran dapat dilakukan di muka, dicicil, atau ditangguhkan. Sementara pada salam, pembayaran dilakukan secara tunai.

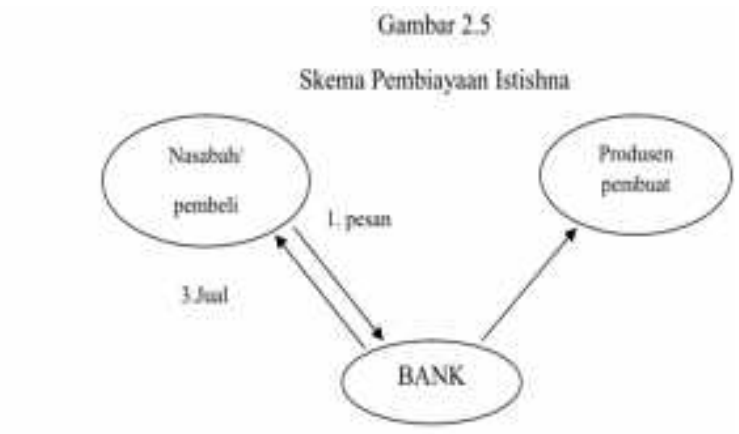

Sumber: Bank Syariah, ituri Toon ke Praktik, Antooin \{200\}

Ijarah

Ijarah Muntahiya Bittamlik merupakan akad atau perjanjian yang merupakan kombinasi antara jual-beli dan sewa-menyewa suatu barang antara bank dengan nasabah di mana nasabah (penyewa) diberi hak untuk membeli atau memiliki obyek sewa pada akhir akad(Pratami, 2011).

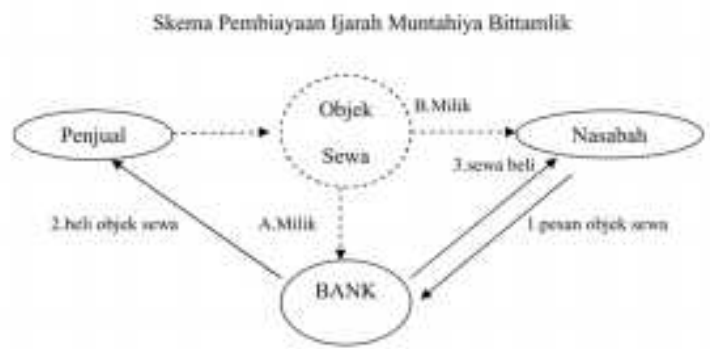

Sumber: Bank Syariah, dari Teori ke Praktik, Antonio (2000)

Implementasi Pembiayaan Mudharabah di Perbankan Syariah Indonesia

Mudharabah biasanya diterapkan pada produk-produk pembiayaan dan pendanaan. Pada sisi penghimpunan dana mudharabah diterapkan pada ; Tabungan berjangka, tabungan yang dimaksudkan untuk tujuan khusus, seperti tabungan haji, tabungan kurban, deposito biasa; deposito spesial (special investment), dimana dana yang dititipkan nasabah khusus untuk bisnis tertentu, misalnya mudharabah saja atau ijarah saja. 
Adapun pada sisi pembiayaan, mudharabah diterapkan untuk; pembiayaan modal kerja, seperti pembiayaan modal kerja perdagangan dan jasa; investasi khusus, disebut juga dengan mudharabah muqayyadah, dimana sumber dana khusus dengan penyaluran yang khusus dengan syarat-syarat yang telah ditetapkan oleh shahib al-mal (bank).

Implementasi Pembiayaan Musyarakah di Perbankan Syariah Indonesia

Implementasi musyarakah dalam perbankan syariah dapat dijumpai pada pembiayaan-pembiayaan seperti: Pembiayaan Proyek Musyarakah biasanya diaplikasikan untuk pembiayaan proyek dimana nasabah dan bank sama-sama menyediakan dana untuk membiayai proyek tersebut, dan setelah proyek itu selesai nasabah mengembalikan dana tersebut bersama bagi hasil yang telah disepakati untuk bank. Modal Ventura Pada lembaga keuangan khusus yang dibolehkan melakukan investasi dalam kepemilikan perusahaan, musyarakah diaplikasikan dalam skema modal ventura. Penanaman modal dilakukan untuk jangka waktu tertentu dan setelah itu bank melakukan divestasi atau menjual bagian sahamnya, baik secara singkat maupun bertahap.

Implementasi Pembiayaan Murabahah di Perbankan Syariah Indonesia

Di Indonesia, aplikasi jual beli murabahah pada perbankan syariah di dasarkan pada Keputusan Fatwa Dewan Syariah Nasional (DSN) Majelis Ulama Indonesia (MUI) dan Peraturan Bank Indonesia (PBI). Menurut keputusan fatwa DSN Nomor 04/DSN-MUI/IV/2000 ketentuan murabahah pada perbankan syariah adalah sebagai berikut: . Bank dan nasabah harus melakukan akad murabahah yang bebas riba, Barang yang diperjualbelikan tidak diharamkan oleh syari'ah Islam. Bank membiayai sebagian atau seluruh harga pembelian barang yang telah disepakati kualifikasinya. Bank membeli barang yang diperlukan nasabah atas nama bank sendiri, dan pembelian ini harus sah dan bebas riba. Bank harus menyampaikan semua hal yang berkaitan dengan pembelian, misalnya jika pembelian dilakukan secara hutang. Bank kemudian menjual barang tersebut kepada nasabah (pemesan) dengan harga jual senilai harga beli plus keuntungannya. Dalam kaitan ini Bank harus memberitahu secara jujur harga pokok barang kepada nasabah berikut biaya yang diperlukan. Nasabah membayar harga barang yang telah disepakati tersebut pada jangka waktu tertentu yang telah disepakati. Untuk mencegah terjadinya penyalahgunaan atau kerusakan akad tersebut, pihak bank dapat mengadakan perjanjian khusus dengan nasabah. Jika bank hendak mewakilkan kepada nasabah untuk membeli barang dari pihak ketiga, akad jual beli murabahah harus dilakukan setelah barang, secara prinsip, menjadi milik bank

Implementasi Pembiayaan Salam di Perbankan Syariah Indonesia

Dalam dunia perbankan syariah, salam merupakan suatu akad jual beli layaknya murabahah. Perbedaan mendasar hanya terletak pada pembayaran serta penyerahan objek yang diperjualbelikan.. Dalam akad salam, pembeli wajib menyerahkan uang muka atas objek yang dibelinya, lalu barang diserahterimakan dalam kurun waktu tertentu. Salam dapat diaplikasikan sebagai bagian dari pembiayaan yang dapat diberikan oleh bank kepada nasabah debitur yang membutuhkan modal guna menjalankan usahanya, sedangkan bank dapat memperoleh hasil dari usaha nasabah lalu menjualnya kepada yang berkepentingan. Ini lebih dikenal dengan salam pararel.(Abrista, 2011).

Aplikasi akad salam dalam bank, bank bertindak sebagai pembeli, sementara nasabah sebagai penjual. Ketika barang telah diserahkan kepada bank, maka bank akan menjualnya kepada rekanan nasabah atau kepada nasabah itu sendiri secara tunai maupun cicilan. Harga beli bank adalah harga pokok ditambah keuntungan (Muhammad, 2005) 
Implementasi Pembiayaan Istisna di Perbankan Syariah Indonesia

Istisna sebagai salah satu akad didasarkan pada prinsip jual beli dapat diimplementasikan dalam produk pembiayaan bank syariah. Bagi bank syariah yang menyediakan produk istisna ini mendasarkan pada SEBI No. 10/14/DPbs tertanggal 17 maret 2008. Dalam kegiatan penyaluran dana dalam bentuk pembiayaan atas dasar akad istisna'berlaku persyaratan paling kurang sebagai berikut :

1. Bank bertindak baik sebgai pihak penyedia danamaupun penjual barang untuk kegiatan transaksi istisna, dengan nasabah sebagai pihak pembeli barang;

2. Barang dalam transaksi istisna' adalah setiap luaran (ouput) yang antara lain berasal dari proses manufacturing atau construction yang melibatkan tenaga kerja, dengan spesifikasi, kualitas, jumlah, jangka waktu, tempat, dan harga yang jelas serta di sepakati oleh kedua belah pihak;

3. Bank wajib menjelaskan kepada nasabah mengenai karakteristik produk pembiayaan atas dasar istisna' serta hak dan kewajiban nasabah sebagaimana diatur dalam ketentuan bank Indonesia mengenai transparansi informasi produk bank dan penggunaan data pribadi nasabah;

4. Bank wajib melakukan analisis atas permohonan pembiayaan atas dasar istisna' dari nasabah yang antara lain meliputi aspek personal berupa analisis atas karakter (character) dan/ atau aspek usaha antara lain meliputi analisis kapasitas usaha (capacity) keuangan (capital), dan /atau prospek usaha (condition);

5. Bank dan nasabah wajib menuangkan kesepakatan dalam bentuk perjanjian tertulis berupa akad pembiayaan atas dasar istisna' ; dan

6. Pembayaran pembelian barang tidak boleh dalam bentuk pembebasan utang atau dalam bentuk pemberian piutang.

Implementasi akad sewa- menyewa dalam produk pembiayaan perbankan syariah

Implementasi akad ijarah (sewamenyewa) dalam lembaga perbankan syari'ah yang terbagi menjadi ijarah murni dan ijarah muntahiya bit tamlik (IMBT) terdapat dalam Surat Edaran Bank Indonesia (SEBI) No. 10/14/DPBS tertanggal 17 Maret 2008 yang merupakan ketentuan pelaksana dari PBI No. 9/19/PBI/2007 tentang Pelaksanaan Prinsip Syariah Dalam Kegiatan Penghimpunan Dana Dan Penyaluran Dana Serta Pelayanan Jasa Bank Syari' ah sebagaimana yang telah diubah dengan PBI No. 10/16/PBI/2008. Selain itu, Implementasi terkait ijarah terdapat dalam SOP yang disampaikan oleh Bank Syari'ah.

Perilaku konsumen merupakan tindakan rasional berdasarkan perpektif konsumen yang dijadikan acuan dalam melakukan kegiatan ekonomi. Dalam arti lain perilaku konsumen juga dapat diartikan sebagai pengorbanan sumber daya terbatas yang telah dikeluarkan konsumen, seperti uang, waktu, ataupun tenaga untuk mendapatkan barang atau jasa yang diinginkan. Kajian mengenai perilaku konsumen menjadi demikian penting dikarenakan dapat menjadi bahan pertimbangan bagi produsen dalam menawarkan output produksinya.

W. Stoner \& D.C. Hague (A Text book of Economic Theory : 1980) dalam Lutfi Efendi (2009) membuat ilustrasi keadaan apabila konsumen dihadapkan pada beberapa pilihan ekonomi, maka tindakan ekonomi yang akan dilakukan adalah sesuai dengan prinsip "economic ratio", Konsumen bertindak rasional dalam arti bahwa konsumen memperoleh kepuasan yang paling besar dari pembeliannya dengan pertimbangan secara teliti dan memilih barang-barang sesuai urutan prioritasnya. Hal ini bukan berarti konsumen bertindak mementingkan diri sendiri dalam arti moral, akan tetapi 
keputusan pembelian barang tersebut juga untuk orang-orang disekitarnya.

Faktor-Faktor yang Mempengaruhi Perilaku Konsumen

Kotler (2000) menyebutkan dalam Wahyuni (2008), bahwa faktor-faktor yang mempengaruhi perilaku konsumen antara lain : faktor kebudayaan, faktor sosial, faktor personal dan faktor psikologis.1). Faktor Kebudayaan yang terdiri atas kultur, SubBudaya dan Kelas Sosial.2). Faktor Sosial. Perilaku seorang konsumen juga dipengaruhi oleh faktor-faktor social diantaranya adalah kelompok sosial, kelompok referensi, serta keluarga. 3). Faktor Pribadi yang di pengaruhi oleh, a) usia dan tahap daur hidup b) Keadaan Ekonomi c) Pekerjaan dan d) Gaya Hidup. Faktor Psikologis, dipengaruhi oleh Motivasi, persepsi, belajar dan kepercayaan sikap.

Menurut Marimin (2004:10) dalam Wachid (2014) dalam mengambil keputusan seseorang seringkali dihadapkan pada berbagai kondisi antara lain unik, tidak pasti, jangka panjang dan kompleks. Pertama, pengertian dari kondisi unik adalah masalah tersebut tidak mempunyai preseden dan di masa depan mungkin tidak akan berulang kembali. Kedua, pengertian dari tidak pasti adalah faktor-faktor yang diharapkan mempengaruhi dan memiliki kadar ketahuan atau informasi yang sangat rendah. Ketiga, pengertian dari jangka panjang adalah implikasinya memiliki jangkauan yang cukup jauh ke depan dan melibatkan sumbersumber usaha yang penting.

Menurut Salusi (2006:53), setiap keputusan mempunyai kehebatan yang berbedabeda. Ada keputusan yang tidak mempunyai makna, sebaliknya ada yang mempunyai makna global yang luar biasa. Ada keputusan yang sangat sederhana, ada yang sangat kompleks. Brinckloe (1977) menawarkan bahwa sebenarnya ada empat tingkat keputusan, yaitu (1) automatic decisions, (2) expected information decision, (3) faktor weighting decision dan (4) dual uncertainty decision. Setiap keputusan, menurutnya, jatuh dalam salah satu katagori itu.

Bank merupakan industri jasa yang tingkat persaingannya besar dalam lingkup nasional maupun internasional, dengan persaingan industry perbankan yang demikian, baik itu konsumen ataupun para pelaku usaha perbankan harus memahami situasinya dengan baik. Untuk itu, menurut Ghazali Mazki (2010) , keputusan pemilihan bank didasarkan kepada : (1) Karakteristik bank; (2) Pemberian bobot pada kepentingan pada ciri-ciri yang relavan di mana banyak calon nasabah lebih mementingkan pada tingkat kesehatan suatu bank ; (3) kepercayaan akan merk bank ; (4) Fungsi utilitas ; (5) Prosedur evaluasi.

Adanya perilaku konsumen yang cenderung enggan menggunakan produk perbankan syariah dari hasil kajian terdahulu berkaitan persaingan pendapatan seperti ditunjukkan pendapatan padagang pasar syariah setelah adanya keberadaan ritel modern ternyata memberikan pengaruh dengan terjadinya penurunan yang drastis. Waldelmi, I. (2017)

\section{METODE}

Penelitian dilaksanakan di kota Pekanbaru dimana ruang lingkup pengumpulan data mencangkup pada 2 bank syariah di kota pekanbaru. Pada penelitian ini yang menjadi objek/ peubah yang diamati, Perilaku konsumen dan diolah adalah Aplikasi produk Salam dan Istisna di wilayah perkotaaan.

Penelitian ini dilakukan dengan pendekatan deskriptif yang mempunyai tujuan utama menguraikan sesuatu karakteristiknya, mengumpulkan data supaya dapat menguji hipotesis yang di ajukan untuk menjawab pertanyaan mengenai keadaan/ atau status dari objek yang di pelajari ( Malhotra, 2015).

Data primer adalah data yang diperoleh dari pengamatan dan observasi secara angsung terhadap obyek yang diteliti melalui kuesioner. Dalam hal ini nasabah bank syariah yang diperoleh melalui kuesioner. Sedangkan data sekunder adalah 
data yang diperoleh dari instansi-instansi atau lembaga yang berkaitan dengan penelitian ini, misalnya studi literature terdahulu, studi kepustakaan, jurnal literatur-literatur yang berkaitan dengan permasalahan.

Analisa data dalam penelitian ini menggunakan metode deskriptif kuantatif yaitu suatu metode dengan mengelompokan data kedalam suatu distribusi frekuensi dan kemudian dianalisis dan dikaitkan dengan teori yang ada setelah itu baru dibuat suatu kesimpulan (Sugiyono, 2010:237).

Data analisis menggunakan metode regresi linier berganda Menurut Iqbal Hasan (2003:254). Untuk melihat persamaan umum regresi linier berganda dapat dilihat dengan metode ini. Analisis regresi berganda merupakan teknik analisis yang umum digunakan dalam menganalisis hubungan dan pengaruh satu variabel terikat (Y) dengan dua atau lebih variabel bebas (X). apabila nilai variabel independen mengalami kenaikan atau penurunan dan untuk mengetahui arah hubungan antara variabel, apakah masing-masing ada hubungan positif atau negatif.

\section{HASIL}

Berdasarkan hasil penelitian yang
telah dilaksanakan pada 100 orang responden, nasabah Bank Syariah yang terdiri dari 44 nasabah Bank Muamalat dan 56 nasabah Bank Syariah Mandiri maka dapat didiskripsikan seluruh variable penelitian sesuai dengan masing - masing item yang penjelasannya dapat di uraikan pada uarain berikut.

Perilaku konsumen nasabah bank syariah di dalam mengkomsumsi produk perbankan syariah antara lain prduk Mudharabah, musyarakat, murabahah, salam, istisna dan ijarah serta lainnya dalam penelitian ini menggunakan 8 item pertannyaan yang uraianya dapat dilihat pada tabel berikut. bahwa perilaku konsumen nasabah perbankan syariah di kota Pekanbaru dalam kategori baik (3.88). Apabila dilihat dari semua item, item tertinggi terdapat pada item (4) Saya merasa nyaman dan tenang setelah menjadi nasabah bank syariah dengan skor (4.28) dan yang terendah pada item (2) Saya menjadi nasabah bank syariah bersama bersama dengan keluarga dengan skor (3.16).

Kualitas Pelayanan perbankan syariah di kota Pekanbaru dalam kategori baik (3.88). Apabila dilihat dari semua item, item tertinggi terdapat pada item (4) Saya mendapatkan kepastian hukum yang dapat dipertanggungjawabkan dari setiap saya melakukan transaksi atas setiap produk pada bank syariah dengan skor (4.2) dan yang terendah pada item (1) Saya merasakan keamanan yang bermutu dari anggunan yang saya jaminkan dengan skor (3.82).

Sistem Bagi Hasil perbankan syariah di kota Pekanbaru dalam kategori baik (4.15). Apabila dilihat dari semua item, item tertinggi terdapat pada item (1) Setiap melaksanakan transaksi saya mendapatkan aqad/ kesepakatan yang menguntungkan atas keduabelah pihak dan tidak ada pihak yang dirugikan dengan skor (4.27) dan yang terendah pada item (2) Saya mendapatkan kejelasan sangsi atas keterlambatan/ melanggar transaksi yang saya lakukan di bank syariah dengan jelas dengan skor (3.97).

Budaya pada perbankan syariah di kota Pekanbaru dalam kategori baik (4.17). Apabila dilihat dari semua item, item tertinggi terdapat pada item (1) Saya memilki pemahaman akan riba bahwa riba hukumnya haram dengan skor (4.58) dan yang terendah pada item (2) Saya melihat bahwa produk bank syariah sudah banyak dengan skor (3.89).

Karakteristik perbankan syariah di kota Pekanbaru dalam kategori baik (3.79). Apabila dilihat dari semua item, item tertinggi terdapat pada item (2) Saya percaya bank syariah di awasi oleh lembaga keuangan Islam dengan skor (4.2) dan yang terendah pada item (1) Saya percaya bank syariah yang ada murni menerapkan unsur syariah dengan skor (3.43).

Apabila dilihat secara persial pengaruh kualitas pelayanan terhadap prilaku konsumen dengan nilai $\mathrm{t}$ hitung

$$
\text { p.ISSN: } 2407-800 X \quad \text { e.ISSN: 2541-4356 }
$$


sebesar 2,326 dengan nilai signifikasi sebesar 0.022 yang berarti lebih kecil dari 0.05 ini bermaknakan bahwa karakteritik bank syariah dalam hal ini bank syariah mandiri dan bank muamalat berpengaruh sigfinifakan terhadap perilaku konsumen nasabah bank syariah. Selanjutnya pada sistem bagi hasil juga berpengaruh significant terhadap perilaku konsumen nasabah bank syariah di kota pekanbaru. Hal ini dapat dilihat dari nilai t hitung sebeesar 2.193 dengan nilai signifikasi sebesar 0.031 lebih kecil dari 0.05 . variable lainnya yakni karakteristik bank juga memberikan pengaruh yang signifikat terhadap perilku konsumen nasabah bank syariah sehinga $t$ hitung sebesar 4.715 dengan $p$ value sebesar 0.00 ini bermakna bahwa karakteristik bank memiliki pengaruh yang significant terhadap perilaku nasabah bank syariah. Hal berbeda terjadi pada variable budaya. Variable budaya tidak berpengaruh signifikan terhadap perilaku konsumen hal ini di buktikan dari nilai $t$ hitung sebesar 0.693 dan nilai signifaksi sebesar 0.490 lebih besar nilai alfa 0,05.

Dari empat variable tersebut dapat dilihat nilai koefisien regresi pertama kualitas pelayanan sebesar 0.426 kemudian sistem bagi hasil 0.550 dan budaya sebesar 0.144 serta karakteristik bank sebesar 0.993 maka tersebut menunjukkan bahwa dari ke empat variable yakni kualitas pelayanan, sistem bagi hasil, budaya, dan karakteristik bank terbukti variable karakteristik bank memberikan pengaruh yang signifikan di bandingankan dengan variable lainnya, diikuti oleh sistem bagi hasil, kualitas pelayanan dan terakhir budaya.

a. Pengaruh secara simultan

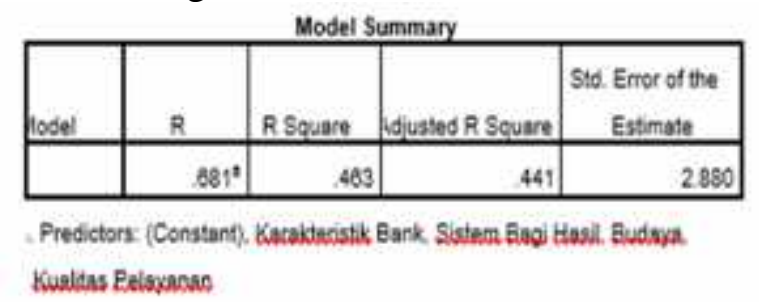

Jurnal Daya Saing

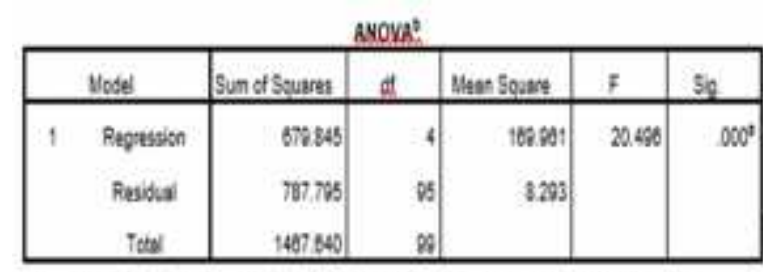

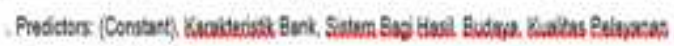

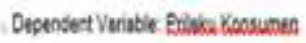

Apabila dilihat kontribusi ke empat variable yakni karakteristik bank, sistem bagi hasil, budaya dan kualitas pelayanan memberikan pengaruh sebesar $46.3 \%$ ini berarti bahwa prilaku konsumen nasabah bank syariah. Mampu di jelaska oleh variable karakteristik bank, sistem bagi hasil, budya dan kualitas pelayanan sebesara 46,3\% sedangkan sisasnya $53,7 \%$ di pengaruh oleh faktor lain yang tidak di teliti pada penelitian ini, seperti contohnya promosi, kepercayaan dan lain sebagainya.

Hal serupa pula dijelaskan dari uji hipotesis secara simultan variable karakteristik bank, sistem bagi hasil, budya dan kualitas pelayanan terhadap prrilaku konsumen dengan nilai $\mathrm{f}$ hitung sebssar 20.496 dan nili $p$ value sesar 0.00 yang atinya bahwa secara silmultan terbukti bahwa ke empat variable (variable karakteristik bank, sistem bagi hasil, budaya dan kualitas pelayanan berpebgaruh significant terhadap prilaku konsumen.

\section{PEMBAHASAN}

Berdasarkan hasil penelitian terbukti bahwa variable yang mempengaruhi perilaku nasabah perbankan syariah yang terdiri dari 4 variable yakni kualitas pelayanan, sistem bagi hasil, budaya dan karakteristik perbankan merupakan faktor yang mempengaruhi perilaku konsumen dengan pengaruh sebesar $46,3 \%$ dan sisanya di pengaruhi oleh faktor yang tidak diteliti pada penelitian ini misalnya promosi, kepercayaan dan lainnya.

Dari empat faktor tersebut ternyata hanya tiga variable yang significant yakni karakteristik bank, sistem bagi hasil dan kualitas pelayanan sedangkan yang tidak berpenagruh significant hal ini dikarenakan 
produk produk syariah yang ditawarkan oleh perbankan seperti Pembiayaan Salam, istisna, mudharabah, musyarakah, murabahah dan ijarah serta lainnya belum membudaya dan juga belum dikenali oleh masyarakat. Selain itu juga dari pihak perbankan itu sendiri belum mau menawarkan produk produk tertentu speerti produk istisna dan salam hal ini karenakan produk istisna dan slaam dinilai tidak menguntukngkan pihak perbankan.

Untuk mengetahui Solusi apa yang dapat diberikan guna mendongkrak penerapan akad Pembiayaan Salam, istisna, mudharabah, musyarakah, murabahah dan ijarah) sebagai instrumen pembiayaan di perbankan syariah.

Solusi yang dapat diberikan dalam rangka merubah perilaku nasabah trehadap bank syariah adalah dengan memperbaiki karakteritik bank dengan berani jujur menawarkan produk perbankkan syariah sebagai mana mestinya dan sebagaimana seharusnya sehingga produk dapat di kenal oleh masyarakat dengan baik dan pada gilirannya masyarakat akan mengkomsumsi produk perbankan syariah tersebut di masa masa yang akan datanng.

\section{SIMPULAN}

Berdasarkan hasil penelitian maka dapat di tarik beberapa kesimpulan sebagai berikut : Dari empat variable tersebut dapat dilihat nilai koefisien regresi pertama kualitas pelayanan sebesar 0.426 kemudian sistem bagi hasil 0.550 dan budaya sebesar 0.144 serrta karakteristik bank sebesar 0.993 maka tersebut menunjukkna bahwa dari ke empat variable yakni kualitas pelayanan, sistem bagi hasil, budaya, dan karakteristik bank terbukti variable karakteristik bank memberikan pengaruh yang signifikan di bandingankan dengan variable lainnya, diikuti oleh sistem bagi hasil, kualitas pelayanan dan terakhir budaya

Hal serupa pula dijelaskan dari uji hipotesis secara simultan variable karakteristik bank, sistem bagi hasil, budaya dan kualitas pelayanan terhadap prilaku konsumen dengan nilai $f$ hitung sebssar Jurnal Daya Saing
20.496 dan nilai $p$ value sesar 0.00 yang atinya bahwa secara silmultan terbukti bahwa ke empat variable (variable karakteristik bank, sistem bagi hasil, budaya dan kualitas pelayanan berpebgaruh significant terhadap prilaku konsumen.

Dari empat faktor tersebut ternyata hanya tiga variable yang significant yakni karakteristik bank, sistem bagi hasil dan kualitas pelayanan sedangkan yang tidak berpenagruh significant hal ini dikarenakan produk produk syariah yang ditawarkan oleh perbankan seperti Pembiayaan Salam, istisna, mudharabah, musyarakah, murabahah dan ijarah serta lainnya belum membudaya dan juga belum dikenali oleh masyarakat.

\section{DAFTAR RUJUKAN}

Basuki, tri, Agus dan Prawoto, Nano. 2016. Analisis Regresi dalam Penelitian Ekonomi dan Bisnis. PT. Raja Grafindo Persada. Jakarta.

Handriano, Rory. 2015. Perbankan Syariah Indonesia : Kinerja Keuangan, Prospek dan Tantangan dalam menyonsong MEA 2015. Dinamika Ekonomi Jurnal Ekonomi dan Bisnis Vol.8 No.2 September 2015, hal $122-125$.

Rio. 2011. Pertumbuhan penduduk Riau.http://riaupos.co.id/news/201 1/06/pertumbuhan penduduk- riau - di atas - standar nasional. $23 \mathrm{Mei}$ 2016.

ISRA (International Shari'ah research Academy for Islamic Finance). 2015. Sistem Keuangan Islam, Prinsip dan operasi. PT. Raja Grafindo Persada. Jakarta.

Waldelmi, I. (2017). Analisis pendapatan pedagang kelontong di pasar syariah ulul albab desa tanah merah dan pandau jaya kecamatan

p.ISSN: 2407-800X e.ISSN: 2541-4356 
siak hulu kabupaten Kampar. Jurnal Daya Saing, 3(2), 181-186.

Januar, Adriano. 2016. Keputusan Nasabah Menabung di Perbankan Syariah (Studi Pada Mahasiswa Universitas Brawijaya Malang). Jurnal ilmiah fakultas Ekonomi dan Bisnis Universitas Brawijaya Malang, hal. $5-8$.

Karim, Adiwarman A. 2014. Bank Islam, Analisis Fiqih dan Keuangan. PT. Raja Grafindo Persada. Jakarta.

Lestari, puji, Enny. 2007. Resiko Pembiayaan dalam Akad Istisna'pada Bank Umum Syariah. Jurnal Hukum dan Ekonomi Syari"ah, Vol. 02 Nomor 1, hal. 4 13.

Perwataatmadja, Karnaen A dan Tanjung, Hendri. 2006. Bank Syariah, Teori, Praktik dan Peranannya. Calestial Publishing. Jakarta.

pratami, W. A. N. (2011). Analisis Pengaruh Dana Pihak Ketiga (Dpk), Capital Adequacy Ratio (Car), Non Performing Financing (Npf) Dan Return On Asset (Roa) Terhadap Pembiayaan Pada Perbankan Syariah. Skripsi.

Qodriasari, I. L. (2014). Analisis Pengaruh Pendapatan Pembiayaan Mudharabah, Musyarakah, Murabahah, Dan Sewa Ijarah Terhadap Profitabilitas Bank Umum Syariah Di Indonesia Periode Tahun 2011-2013. Naskah Publikasi/ Skripsi, $16 \mathrm{H}$.
Wiwiek Rabiatul Adawiyah. (2010). Pertimbangan, pengetahuan, dan sikap konsumen individu terhadap bank syariah. Jurnal Ekonomi Pembangunan Volume 11, Nomor 2, Desember 2010, hlm.191-201, 11, 191-201.

Sholihah, Isfi. 2015. Analisis Faktor faktor yang Mempengaruhi Persepsi Masyarakat Tentang Perbankan Syariah di Kecamatan Selong Kabupaten Lombok Timur. Jurnal Education Vol. 10 No. 1, Juni 2015, hal. 77 -78.

Umam, Khotibul. 2016. Perbankan Syariah, dasar - dasar dan dinamika perkembangannya di Indonesia. PT. Raja Grafindo Persada. Jakarta.

Wiwik, Fitria, Ningsih. 2015. Modifikasi Pembiayaan Salam dan Implikasi Perlakuan Akuntansi Salam. Jurnal Akuntansi Universitas Jember - Vol. 13 No. 2 Desember 2015, hal $17-24$. 